\title{
Faktor-Faktor yang Mempengaruhi Profesionalisme Guru
}

\author{
H.M. Syarafudin ${ }^{1}$, Hastuti Diah Ikawati ${ }^{2}$ \\ 1,2 Dosen FIPP Undikma \\ email: hastutidiahikawati@ikipmataram.ac.id
}

\begin{abstract}
Abstrak, Penelitian ini bertujuan untuk menjelaskan dan menganalisis faktor-faktor yang mempengaruhi profesionalisme guru. Guru adalah seseorang tenaga pendidik professional yang mendidik, mengajarkan suatu ilmu, mengarahkan, melatih, memberikan penilaian, serta melakukan evaluasi kepada peserta didik. Sementara itu, standard kompetensi yang tertuang dalam peraturan Menteri Pendidikan Nasional mengenai standar kualifikasi akademik serta kompetensi guru dimana peraturan tersebut menyebutkan bahwa guru profesional harus memiliki 4 kompetensi profesional yaitu kompetensi pedagogik, kompetensi sosial, kompetensi intelektual serta profesional. Ada beberapa faktor yang mempengaruhi profesionalismenya seorang guru diantaranya yaitu kualifikasi standar guru dan relevansi antara bidang keahlian guru dengan tugas mengajar, abilitas dan motivasi, tingkat pendidikan guru, pengalaman kerja, penguasaan kompetensi social, pedagogic dan keterampilan.
\end{abstract}

Kata kunci : guru, kompetensi, profesionalisme

Abstract, This study aims to explain and analyze the factors that influence teacher professionalism. The teacher is a professional educator who educates, teaches knowledge, directs, trains, gives assessments, and evaluates students. Meanwhile, the competency standards set out in the Minister of National Education's regulations regarding academic qualification standards and teacher competencies where the regulation states that professional teachers must have 4 professional competencies, namely pedagogical competence, social competence, intellectual and professional competence. There are several factors that affect the professionalism of a teacher including the standard qualifications of teachers and the relevance of the teacher's field of expertise with teaching assignments, ability and motivation, the level of teacher education, work experience, mastery of social competence, pedagogic and skills.

Keywords: teacher, competence, professionalism

\section{PENDAHULUAN}

Pendidikan merupakan salah satu aspek dalam kehidupan yang berperan penting dalam meningkatkan kualitas hidup manusia. pendidikan adalah usaha sadar untuk menyiapkan peserta didik melalui kegiatan bimbingan, pengajaran atau latihan bagi peranannya dimasa yang akan datang. Pendidikan mulai diterapkan dalam kehidupan seseorang semenjak dalam kandungan hingga dimasukkan ke liang lahat mengalami proses pembelajaran baik yang terjadi secara alamiah maupun yang dilangsungkan secara sistematis dan terstruktur yang terpola secara berjenjang dalam suatu lembaga pendidikan yang diselenggarakan secara formal maupun nonformal. Dengan demikian, pendidikan pada dasarnya merupakan kegiatan yang bersifat universal yang berlangsung sejak terbentuknya masyarakat.

Di Indonesia, pelaksanaan kegiatan pendidikan ini diatur sesuai dengan tujuan nasional yang tercantum dalam pembukaan UUD 1945 yang berbunyi “.... Untuk membentuk suatu pemerintah negara Indonesia yang melindungi segenap bangsa Indonesia dan seluruh tumpah darah Indonesia dan untuk memajukan kesejahteraan umum,

mencerdaskan kehidupan bangsa dan ikut melaksanakan ketertiban dunia yang berdasarkan kemerdekaan, perdamaian abadi, dan keadilan sosial....".

Dalam menciptakan pembelajaran yang efektif maka diperlukan guru yang harus memiliki kualifikasi akademik minimum dan sertifikasi sesuai dengan jenjang kewenangan mengajar (UU RI No.20 Tahun 2003 Pasal 42 dan PP RI No. 19 Tahun 2005 Bab VI Pasal 28). Program sertifiksasi kepada guru akan menjadi control yang mendorong para penyelenggara pendidikan untuk meningkatkan profesionalismenya dan memberikan layanan maksimal kepada para stakeholder. Program sertifikasi merupakan implikasi dari UU No. 14 Tahun 2005 tentang guru dan dosen. 


\section{LITERATUR REVIEW}

\section{Frofesionalisme Guru}

Menurut UU No. 14 Tahun 2005 Tentang Guru dan Dosen, guru adalah tenaga pendidik profesional yang memiliki tugas utama untuk mendidik, mengajar, membimbing, mengarahkan, melatih, menilai dan mengevaluasi peserta didik pada pendidikan anak usia dini melalui jalur formal pendidikan dasar dan pendidikan menengah.

Menurut Husnul Khotimah (2008), guru adalah orang yang memfasilitasi proses peralihan ilmu pengetahuan dari sumber belajar kepada peserta didik. Jadi, guru adalah seseorang tenaga pendidik professional yang mendidik, mengajarkan suatu ilmu, mendidik,mengarahkan, melatih, memberikan penilaian, serta melakukan evaluasi kepada peserta didik.

Sebagai kata benda, profesional lebih berarti orang yang melaksanakan sebuah profesi dengan menggunakan profesi sebagai mata pencaharian (Mc. Leod, 1989). Sedangkan guru dalam kamus bahasa Indonesia edisi kedua (1991), diartikan sebagai orang yang pekerjaannya atau mata pencahariannya mengajar. Sementara itu, dalam UU No. 14 Tahun 2005 tentang guru dan dosen, yakni sebagaimana tercantum dalam bab 1 ketentuan umum pasal 1 ayat 1 , guru adalah pendidik profesional dengan tugas utama, mendidik, mengajar, membimbing, mengarahkan, melatih menilai dan mengevaluasi peserta didik pada pendidikan dasar dan menegah.

Di dalam UU No. 20 Tahun 2003 tentang sistem pendidikan nasional, pada pasal 39 ayat 2 menjelaskan bahwa pendidik merupakan tenaga profesional yang bertugas merencanakan dan melaksanakan proses pembelajaran, menilai hasil pembelajaran, melakukan pembimbingan dan pelatihan serta melakukan penelitian dan pengabdian kepada masyarakat.

Komarudin (2000 : 205) mengemukakan bahwa profesional berasal dari bahasa latin yaitu "profesia", pekerjaan, keahlian, jabatan, jabatan guru besar. Seorang yang melibatkan diri dalam salah satu keahlian yang harus dipelajari dengan khusus.Jarvis dalam Sagala (2006:198) profesional dapat diartikan bahwa seseorang yang melakukan tugas profesi juga sebagai ahli (expert) apabila dia secara spesifik memperolehnya dari belajar. Sedangkan Tilaar (2002:86) mengemukakan bahwa:Seorang profesional menjalankan pekerjaannya sesuai dengan tuntutan profesi atau dengan kata lain memiliki kemampuan dan sikap sesuai dengan tuntutan profesinya.

Adapun guru yang profesional itu sendiri adalah guru yang berkualitas, berkompeten dan guru yang dikehendaki untuk mendatangkan prestasi belajar serta mampu mempengaruhi proses belajar siswa yang nantinya akan menghasilkan prestasi belajar siswa yang lebih baik.

Guru sebagai tenaga profesional harus memenuhi beberapa kriteria, yaitu :

a. Mempunyai komitmen terhadap siswa dan proses belajarnya;

b. Menguasai mata pelajaran yang diajarkannya serta cara mengajarnya kepada siswa

c. Bertanggung jawab memantau hasil belajar siswa melalui berbagai cara evaluasi, dan

d. Mampu berpikir sistematis tentang apa yang dilakukannya dan belajar dari dari lingkungan profesinya. (Hasan, 2003:5)

Raths (Sukmadinata, 2002:192) mengemukakan bahwa untuk menjadi guru yang profesional dan berkualitas, ada 12 kemampuan yang harus dimiliki oleh guru yaitu : (1) Explaining, informing, showing how, (2) Initiating, Directing, administering, (3) Unifying the group, (4) Giving security, (5) Clarifying attitudes, beliefs, problems, (6) Diagnosing learning problems, (7) Making curriculum materials, (8) Evaluating, recording, reporting, (9) enrichment community activities, (10) Organizing and arranging classroom, (11) participating in professional and civic life, and (12) participating in school activities.

Sagala (2005:210) mengemukakan guru yang profesional harus memiliki sepuluh kompetensi dasar, yaitu :

a. Menguasai landasan-landasan pendidikan

b. Menguasai bahan pelajaran

c. Kemampuan mengelola program belajar mengajar

d. Kemampuan mengelola kelas

e. Kemampuan mengelola interaksi belajar mengajar 
f. Menilai hasil belajar siswa

g. Kemampuan mengenal dan menterjemahkan kurikulum

h. Mengenal fungsi dan program bimbingan dan penyuluhan

i. Memahami prinsip-prinsip dan hasil pengajaran

j. Mengenal dan menyelenggarakan administrasi pendidikan

Untuk menciptakan sosok aparatur pendidikan yang profesional dan mempunyai kompetensi yang tinggi diperlukan pembinaan karier guru yang jelas dan berkelanjutan. Di dalam kegiatan proses belajar mengajar di kelas guru harus didukung dengan terpenuhinya kebutuhan internal eksternal. Situasi eksternal guru sering menjadikan kondisi internal menjadi tidak seimbang. Dalam hal ini kepuasan guru pada kondisi eksternal yaitu lingkungan sekolah, gaji yang tidak memadai, sistem pembinaan yang tidak teratur dapat menyebabkan kondisi internal guru menjadi terganggu.Agar kondisi internal guru dapat terjaga dengan baik dibutuhkan kemampuan untuk mengontrol kondisi hati sehingga tidak menimbulkan stress. Kemampuan guru untuk memahami, merasakan dan menerapkan daya serta kepekaan emosi terintegrasi dalam situasi pembelajaran akan menyebabkan proses pembelajaran dapat berjalan efektif.

2. Karakteristik Guru Profesional

Seorang guru yang profesional dituntut dengan sejumlah persyaratan minimal, antara lain: memiliki kualifikasi pendidikan profesi yang memadai, memiliki kompetensi keilmuan sesuai dengan bidang yang ditekuninya, memiliki kemampuan berkomunikasi yang baik dengan anak didiknya, mempunyai jiwa kreatif dan produktif, mempunyai etos kerja dan komitmen tinggi terhadap profesinya, dan selalu melakukan pengembangan secara terus menerus melalui organisasi profesi, internet, buku, seminar, dan semacamnya.

3. Faktor-Faktor Yang Mempengaruhi Profesionalisme Guru

Profesionalisme guru dipengaruhi oleh beberapa faktor dan merupakan permasalahan, yaitu faktor "kualifikasi standar guru dan relevansi antara bidang keahlian guru dengan tugas mengajar (Taufik, 2002:244). Gibson et al (1985:51-53) mengemukakan bahwa "ada tiga kelompok variabel yang mempengaruhi profesional guru , yaitu pertama variabel individu, variabel organisasi dan variabel psikologis individu".

Cascio (Sukmadinata, 2004:21) menyatakan bahwa "abilitas dan motivasi merupakan faktor-faktor yang berinteraksi dengan kinerja, profesionalisme berhubungan dengan kinerja." Faktor-faktor yang tidak langsung mempengaruhi kinerja ialah manusia, modal, metode, produksi, lingkungan organisasi, lingkungan negara, lingkungan regional dan umpan balik.

Selain faktor-faktor tersebut di atas yang perlu diperhatikan dan dikuasai guru agar profesional dan berkinerja tinggi di era informasi, guru juga perlu menguasai sejumlah standar kompetensi dan penjabaran berbagai sub kompetensi dan pengalaman belajar yang terkandung dalam kompetensi pedagogik, sosial dan kepribadian sesuai rumusan yang dihasilkan oleh Asosiasi LPTKI Indonesia tahun 2006. Masalah kualifikasi juga merupakan faktor yang mempengaruhi profesionalisme dan kinerja guru untuk menunjukkan profilnya sebagai guru berkualitas sesuai dengan tuntutan era informasi dalam era globalisasi.

Faktor-faktor Yang Mempengaruhi Profesionalisme Guru dilihat dari perspektif Input-Proses-Ouput. Dari beberapa faktor yang mempengaruhi profesionalisme guru dapat dibedakan/dikelompokkan menjadi tiga bagian yaitu dari perspektif masukan (input), proses dan perspektif keluaran (output). Yang dimaksud dengan perspektif masukan adalah hal-hal yang terdapat dalam pribadi guru yaitu mencakup kualifikasi atau tingkat pendidikan guru, masa kerja, pengalaman kerja, latihan yang dijalani, penguasaan kompetensi sosial, pedagogik dan keterampilan. Selain itu ada pula faktor input yang berasal dari lingkungan di sekitar guru seperti faktor kepemimpinan kepala sekolah, iklim kerja di sekolah, dukungan dari keluarga, dukungan dari dewan sekolah/komite sekolah, peserta didik dan masyarakat.

Faktor-faktor yang mempengaruhi profesionalisme guru dilihat dari perspektif proses belajar-mengajar di kelas mencakup faktor-faktor motivasi mengajar dan mendidik yang tinggi pada diri guru, motivasi dan minat belajar yang tinggi pada diri peserta didik untuk belajar di sekolah, ketersediaan media dan sumber belajar di sekolah yang memadai, penguasaan guru dalam aplikasi psikologi pendidikan dalam proses pembelajaran di kelas, penguasaan guru dalam aplikasi pengetahuan tentang 
perkembangan peserta didik dalam proses pembelajaran di kelas, penguasaan guru terhadap landasan pendidikan di kelas, penguasaan guru dalam aplikasi berbagai metode, strategi pembelajaran yang inovatif di kelas, penguasaan guru tentang berbagai teori belajar mutakhir yang relevan dalam pembelajaran di kelas, penguasaan guru terhadap aplikasi metode evaluasi proses dan hasil pembelajaran yang inovatif, penguasaan guru terhadap aplikasi teori bimbingan konseling dalam mengatasi kesulitan belajar peserta didik, penguasaan guru dalam aplikasi teori administrasi pendidikan dalam pembelajaran di kelas, kemampuan guru menguasai materi pelajaran dan mengelola PBM secara profesional, kedisiplinan guru dan peserta didik dalam belajar, bekerja dan mengajar di kelas, kemampuan guru dalam mengkaji metodologi keilmuan bidang studi, kemampuan guru dalam menguasai struktur dan materi kurikulum, kemampuan guru mengidentifikasi substansi materi bidang studi sesuai perkembangan dan potensi peserta didik, kemampuan guru memilih substansi, cakupan dan tata urut materi pembelajaran secara konstekstual, kemampuan guru menggunakan teknologi komunikasi dan informasi dalam pembelajaran secara kontekstual, kemampuan guru dalam melaksanakan penelitian tindakan kelas, kemampuan guru dalam berkomunikasi sosial dengan peserta didik di kelas, dan kemampuan guru dalam mendesain peningkatan mutu pembelajaran sesuai hasil penelitian tindakan kelas.

Faktor-faktor yang mempengaruhi profesionalisme guru dilihat dari perspektif keluaran (output) yaitu mencakup faktor-faktor profesionalitas dan kinerja lulusan sekolah di dunia kerja atau di masyarakat, respon dan penghargaan masyarakat dan dunia kerja terhadap lulusan sekolah, dan perilaku teladan yang ditunjukkan oleh para lulusan sekolah di dunia kerja dan di masyarakat.

\section{KESIMPULAN}

Sebagai salah satu faktor pendukung terhadap keberhasilan pendidikan, para guru harus memperhatikan berbagai faktor yang bersumber pada komponen masukan, proses dan keluaran agar menjadi guru yang profesional dan berkinerja tinggi. Ciri guru seperti inilah yang dibutuhkan dalam era informasi dan globalisasi sebagai cermin guru yang bermutu.

Namun, harus disadari bahwa guru yang profesional dan berkinerja tinggi dalam melakukan proses pendidikan di sekolah, tak lahir jika tidak ada niat yang suci dan tulus dari para guru untuk mengetahui, memahami, memperhatikan, menghayati, dan menerapkan berbagai faktor-faktor tersebut untuk meningkatkan profesionalismenya.

Selain itu, para kepala sekolah, orang tua peserta didik, masyarakat, pemerintah, dan semua pemerhati pendidikan, hendaknya selalu memberikan perhatian, bimbingan dan dorongan kepada guru dalam meningkatkan profesionalismenya. Harus disadari guru sebagai komponen mikro dari sistem pendidikan secara makro, tidak akan dapat meningkatkan profesionalismenya jika tidak ada kerjasama yang sinergis dan harmonis dengan berbagai pihak, misalnya kepala sekolah, staf sekolah, peserta didik, orang tua peserta didik, masyarakat, pemerintah, dan dunia kerja sebagai komponen dari sistem pendidikan.

\section{REFRENSI}

Dewi, Tiara Anggia. 2015. Pengaruh Profesionalisme Guru dan Motivasi. https://s3.amazonaws.com/academia.edu.documents/52411991/148-250-1-SM.pdf?responsecontentdisposition=inline $\% 3 B \% 20$ filename\%3DPENGARUH_PROFESIONALISME_GURU_DAN_MO TIVA.pdf\&X-Amz-Algorithm=AWS4-HMAC-SHA256\&X-Amz-

Credential=ASIATUSBJ6BAAVD2KJG7\%2F20200505\%2Fus-east-1

Hanafi, Halid., dkk. 2018. Profesionalisme Guru Dalam Pengelolaan Kegiatan Pembelajaran Di Sekolah. Yogyakarta : CV. Budi Utama. https://www.gurupendidikan.co.id/kompetensi-guru/

Mawardi, Pitalis. 2019. Penelitian Tindakan Kelas, Penelitian Tindaklan Sekolah dan Best Practice. Jawa Timur : CV. Penerbitan Qiara Media.

Pasaribu, Togummar Bondar. 2014. Analisis Faktor-Faktor Yang Mempengaruhi Profesionalisme guru Sekolah Dasar Negeri Di Kelurahan Kapuk Kecamatan Cengkareng. 


$\begin{array}{ccccccc}\text { Jurnal } & \text { Ekonomi } & \text { Bisnis } & \text { Indonesia } & \text { Vol } & 9 & \text { No } \\ \text { https://jurnal.stiebi.ac.id/index.php/Jebi/article/view/64 } & & & 02 . \\ \text { Purba, Saut. } & \text { 2013. Faktor-faktor } & \text { Yang } & \text { Mempengaruhi } & \text { Profesionalitas } \\ \text { Mengajar } & \text { Guru } & \text { Pendidikan } & \text { Vokasi } & \text { Di } & \text { Indonesia. } \\ \text { http://digilib.unimed.ac.id/9s86/2/FullText.pdf saut purba 2013 } & & \\ \text { Safitri, Dewi. 2019. Menjadi Guru Profesional. Riau : PT. Indragiri Dot Com. }\end{array}$

